\title{
Mechanisms and biological effects of Caffeine on substrate metabolism homeostasis: A systematic review
}

\author{
Luiz Augusto da Silva ${ }^{1,3^{*}}$, Jéssica Wouk ${ }^{2}$, Vinícius Müller Reis Weber ${ }^{2}$, Camila da Luz Eltchechem², Pablo de Almeida ${ }^{3}$, \\ Julio Cesar Lacerda Martins ${ }^{3}$, Carlos Ricardo Maneck Malfatti ${ }^{2}$, Raul Osiecki ${ }^{1}$ \\ ${ }^{1}$ Post-graduation of Physical Education, Federal university of Paraná, Curitiba, Paraná, Brazil. \\ ${ }^{2}$ Post-graduation of Pharmaceutical Science, Midwest State University of Paraná, Guarapuava, Paraná, Brazil. \\ ${ }^{3}$ Physical Education Department, Guairacá College, Guarapuava, Paraná, Brazil.
}

\section{ARTICLE INFO}

Article history:

Received on: $16 / 03 / 2017$

Accepted on: 26/04/2017

Available online: 30/06/2017

Key words:

Diabetes, Caffeine, Exercise,

Glycemia.

\begin{abstract}
Objective: This review aims to elucidate the possible effects of caffeine over homeostasis mechanism of energetic subtracts metabolism.

Methods: The study was carried out in systematic review form and its sample comprised six scientific papers published in academic journals. Only the studies involving soccer players (professionals and amateurs, except goalkeepers) were included in this review.

Results: Caffeine was able to increase insulin and serum glycemia levels, after oral glucose tolerance test (OGTT), demonstrating that caffeine alters blood glucose maintenance in diabetic men. A decrease of insulin sensibility evaluated by insulin sensibility index (ISI) rates was observed. Also showed that the administration of caffeine was able to control the catecholamine levels. Nevertheless, demonstrated that long-term consumption of caffeine may be efficient in controlling glucose and adiponectin levels, which would be good for the prevention as well as for the associated complication of diabetes mellitus.

Conclusion: Caffeine is one of the active compounds of coffee and its consumption is being suggested as benefic over glucose tolerance. Albeit, acute and chronic studies are demonstrating controversial results, showing differences in blood glucose levels, such as enhancement, reduction and also, no changes, after the consumption of different doses of caffeine. The mechanism to explain this events is yet unknown, however it is suggested that caffeine may act over insulin clearance. Some studies are aiming to evaluate the action of caffeine over insulin sensibility. Caffeine may act reducing insulin sensibility over its receptors.
\end{abstract}

\section{INTRODUCTION}

Diabetes mellitus type 2 (DMT2) is a chronic disease associated with high rates of morbidity, followed by long term complications and premature mortality (Nathan, 1993; WHO, 2016). Coffee is the most consumed beverage in the world and

* Corresponding Author

E-mail: asilva7@hotmail.com its consumption is being associated with lower risk of diabetes, but a few is known about the mechanisms responsible to this association (van Dam and $\mathrm{Hu}, 2005$; van Dam et al., 2006; Sartorelli et al., 2010). Caffeine is one of coffee's active component and its beneficial effects over glucose tolerance are being deeply investigated (van Dam et al., 2006; Sartorelli et al., 2010). Controversial results were found in acute and chronic studies using caffeine, reporting differences in blood glucose levels 
such as an enhancement (Robinson et al., 2004; Battram et al., 2006; Moisey et al., 2008), reduction (Urzúa et al., 2012; Conde et al., 2012; Guarino et al., 2013) or no changes (Urzúa et al., 2012; Conde et al., 2012; Guarino et al., 2013) after the consumption of different doses of caffeine.

\section{Caffeine mechanism of action}

Adenosine is an important component of purinergic system, and it is found in all tissues presenting a modulatory role in several physiological processes (Fredholm et al., 1999). Adenosine acts through four subtypes of receptors, however, $\mathrm{A}_{1}$ and $\mathrm{A}_{3}$ receptors found in the skeletal muscle, adipose, and liver cells, may be connect to $G$ protein, inhibiting the activity of the enzyme adenylyl cyclase. This inhibition activate the $G$ protein which, suppress the conversion of ATP to cAMP, decreasing the levels of second messenger, not activating protein kinase A (PKA) that act to stimulate skeletal muscle, adipose, and liver cells (Raney and Turcotte., 2008).

Methylxanthine, as caffeine, are competitive antagonists, not selective of adenosine receptors (Conde et al., 2012). Caffeine is more potent to $\mathrm{A}_{2 \mathrm{~A}}$ receptors and less potent to $\mathrm{A}_{3}$ receptors (Fredholm et al., 1999). The action of caffeine over $\mathrm{A}_{2 \mathrm{~A}}$ receptors increases the concentration of intracellular cAMP, triggering several responses, such as metabolic (lipolysis and glycogenolysis in muscle; glycogenesis in liver), cardiovascular (vasoconstriction) and neuronal (glutamate release) (Fredholm et al., 1999).

In addition, caffeine stimulates through the action over adenosine receptors, $\mathrm{Ca}^{2+}$ release in sarcoplasmic reticulum (SR), acting by the activation of $\mathrm{Ca}^{2+} /$ calmodulin-dependent protein kinase II (CaMKII), which is involved in other cascades of enzymatic activation in the cell (Rose e Richter, 2005; Canto et al., 2006).

Caffeine is being shown to be related with the regulation of glucose and lipid metabolism in skeletal muscle. Studies observed that caffeine may increase the concentration of different glucose carriers (GLUT), such as GLUT2 and GLUT4 (Canto et al., 2006; Wright et al., 2005; Park et al., 2009). Caffeine stimulates the insulin-independent glucose carrier (Wright et al. 2004; Jensen et al. 2007) and enhances the expression of RNAm of GLUT4 and fatty acids metabolism (Mukwevho et al., 2008), presenting metabolic effects similar to 5'-AMP activated protein kinase (AMPK). AMPK is a metabolic sensor which has an important role in lipid metabolism regulation, as well as in glucose homeostasis. By the simultaneous inhibition of lipogenesis and lipolysis in adipose tissue, the activation of AMPK decreases the stratified lipid circulation and fat deposition (Long and Zierath 2006); increases lipid oxidation in liver and muscle (Luo et al., 2005; Ruderman and Saha 2006), contributing to an improvement in insulin sensibility in the organism. AMPK reduces liver glucose production and enhances glucose capture in skeletal muscle, presenting an important role in glucose homeostasis. It is being demonstrated that caffeine increases GLUT4 mRNA and insulin independent carriers in skeletal muscle through processes mediated by AMPK (Egawa et al., 2009). The $\mathrm{Ca}^{2+}$ released by SR is a prerequisite to muscle contraction, and may be a sign to the muscle to capture more blood glucose (Rose and Richter, 2005; Canto et al., 2006). Two parallel pathways of glucose uptake stimulation, AMPK or CaMKII are necessary and sufficient to maintain muscular glucose input, in order to obtain enough energy to muscular contraction (Wright et al., 2004; Wright et al., 2005 Raney and Turcotte., 2008). Caffeine may stimulate $\mathrm{Ca}^{2+}$ release of SR (Canto et al., 2006, Wright et al., 2004; Wright et al., 2005), increasing the phosphorylation of AMPK and activating CaMKII, enhancing the translocation of GLUT4, triggering a greater glucose uptake.

Beyond glucose, fatty acids are important to the maintenance of cellular energy. The liberation of $\mathrm{Ca}^{2+}$ by $\mathrm{SR}$ in physical stimulus result in an enhancement of fatty acid harvesting, through the increase of AMPK phosphorylation and a consequent increase of kinase proteins regulated by extracellular sign 1 and 2 (ERK1/2), activated by CaMKII (Rose and Hargreaves, 2003; Wright et al., 2005). Caffeine affects the glucose harvesting (Wright et al., 2004) by intracellular $\mathrm{Ca}^{2+}$ increase and activation of AMPK, however, the fatty acids harvesting could be evolved through the increase of ERK1/2 action becoming a parallel metabolic pathway.

Thus, the description of caffeine effect over glucose and fatty acids harvesting and oxidation in skeletal muscle tissue, as well as the mobilization of adipose tissue already mentioned, demonstrate the complex maintenance pathway of the body metabolic homeostasis (Figure 1).

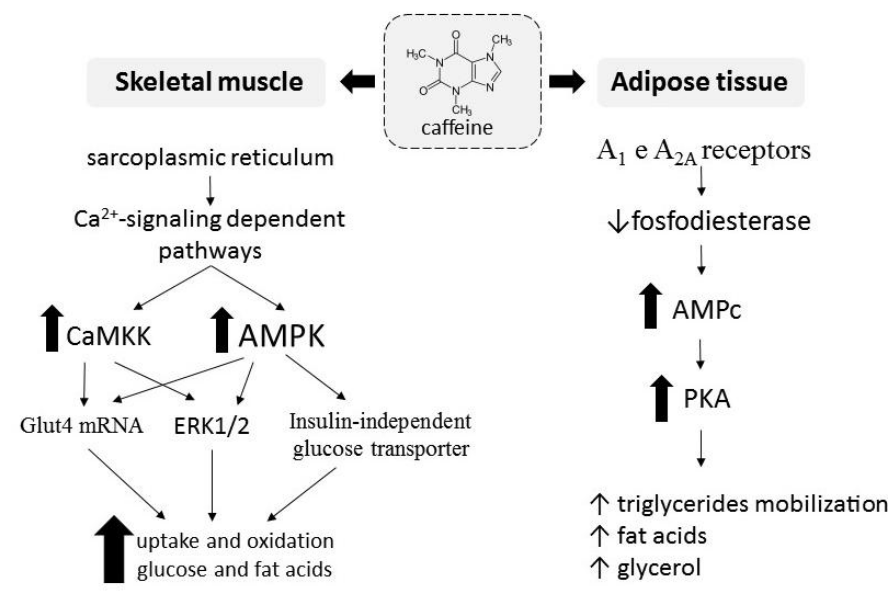

Fig. 1: Possible mechanism of fatty acid and glucose harvesting in skeletal muscle cell and in adipocyte by caffeine.

The relation between caffeine and diabetes, reported by the letter of Kerr and Evert (2005), and demonstrated in initial studies (van Dam et al., 2004, Yamaji et al., 2004), is that the consumption of coffee reduces the risk of developing DMT2. The mechanisms are yet unknown, but it is suggested that it can act over insulin release and action. Some studies are aiming to evaluate the action of caffeine over insulin sensibility, and this effect could be of reducing the sensitivity of insulin over its receptors. Therefore, this review aims to elucidate possible effects 
of caffeine over homeostasis mechanism of energetic subtracts metabolism.

\section{Methods}

This systematic review of literature was conducted in the period of November 2015 and October 2016 utilizing databases such as PubMed, Lilacs, Scielo, Bireme, Google Scholar and Science Direct. In order to obtain the studies, the following keywords were utilized: "Diabetes mellitus", "Metabolism and Caffeine", "Caffeine and Glucose", "Caffeine and Diabetes", "Caffeine and insulin sensibility", "Caffeine and insulin secretion" and "Caffeine, Diabetes and glucose uptake". Furthermore, studies that were cited in the selected articles were verified.

Studies on association of caffeine, diabetes and exercise were included. Those excluded were: a) association between exercise and diabetes only; b) association between caffeine and diabetes only; c) association between exercise and caffeine only; d) studies that utilized other isolated or concomitant supplementation.

\section{RESULTS}

From the researches made in the mentioned databases, there were 654 articles related to the key-words, from which, based on the titles scanning, 88 studies were separated in order to read the respective abstracts. After reading, 39 articles were selected to a complete reading and from these, 13 studies matched with the inclusion criteria and then were selected to this review.

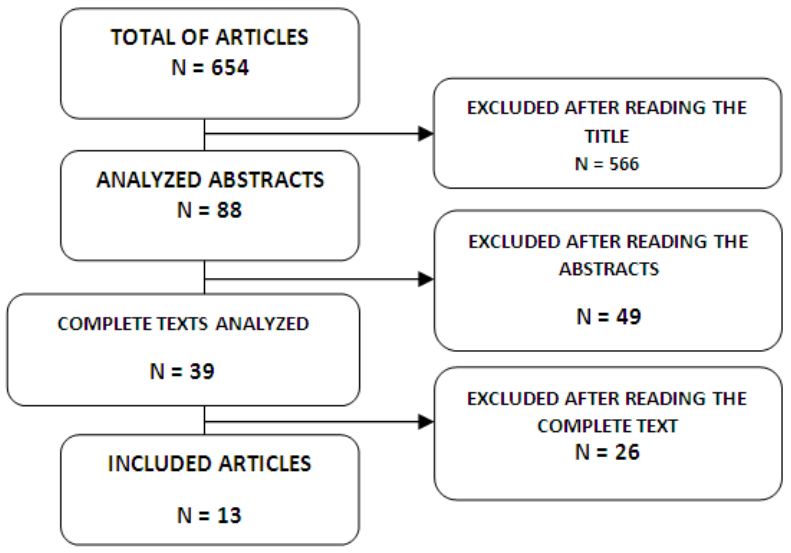

Fig. 2: Organogram of the stages to sample delimitation.

In table 1 there are twelve articles in which caffeine intake analysis in situation of metabolic assessment, with preclinical models (animals) and clinical ones (humans).

Table 1: Baseline characteristics of articles which reported effects of caffeine on homeostasis mechanism of energetic subtracts metabolism.

\begin{tabular}{|c|c|c|c|c|}
\hline Author & $\begin{array}{l}\text { Dose of } \\
\text { caffeine }\end{array}$ & Diabetes mellitus models & Assessment & Biological effects \\
\hline $\begin{array}{l}\text { Battram et al. } \\
\quad(2006)\end{array}$ & $4,5 \mathrm{mg} / \mathrm{kg}$ & Healthy men & OGTT & $\begin{array}{l}\uparrow \text { insulin and peptide } \mathrm{C} \text {; } \\
\uparrow \text { glycemia }(50 \%) 90 \mathrm{~min} \\
\uparrow \text { glycerol } \\
\uparrow \text { epinephrine }\end{array}$ \\
\hline $\begin{array}{l}\text { Bhaktha et al. } \\
\text { (2015) }\end{array}$ & $\mathrm{N} / \mathrm{E}$ & $\begin{array}{l}220 \text { Healthy men and } 48 \text { man } \\
\text { with DMT2 }\end{array}$ & $\begin{array}{l}\text { Blood analyses }(5 \mathrm{~mL}) \text { in } \\
\text { fasting }\end{array}$ & $\begin{array}{l}\downarrow \text { glycemia }(11 \%) \\
\uparrow \text { adiponectin }(20 \%) \\
\downarrow \text { HbAlc }(4,5 \%)\end{array}$ \\
\hline Chu et al. (2011) & $\mathrm{N} / \mathrm{E}$ & Human cells in vitro & $\begin{array}{l}\text { Hepatocytes with carcinoma } \\
\text { HEPG2 and adipose cells }\end{array}$ & $\begin{array}{l}\downarrow \text { ORAC } \\
\downarrow \text { NF-kB } \\
\uparrow \text { glucose uptake (??) }\end{array}$ \\
\hline $\begin{array}{l}\text { Conde } \text { et al } \\
\text { (2012) }\end{array}$ & $6,78 \mathrm{mg} / \mathrm{kg}$ & $\begin{array}{l}\text { Wistar rats with high fat and } \\
\text { dextrose diet }\end{array}$ & ITT & $\begin{array}{l}\downarrow \text { glycemia }(19 \%) \\
\downarrow \text { insulin }(10 \%) \\
\uparrow \text { insulin sensibility }(45 \%) \\
\downarrow \text { FFA }(35 \%) \\
\downarrow \text { catecholamine }(124 \%) \\
\end{array}$ \\
\hline $\begin{array}{l}\text { Egawa } \text { et al } \\
\text { (2009) }\end{array}$ & $3 \mathrm{mmol} / \mathrm{L}$ & 97 male Sprague-Dawley rats & $\begin{array}{l}\text { Rat epitrochlearis and soleus } \\
\text { muscles }\end{array}$ & $\begin{array}{l}\uparrow \text { AMPK }(40 \%) \\
\uparrow \text { Acetyl-CoA carboxylase }(50 \%) \\
\uparrow 3 \text {-O-methyl-D- glucose carrier }(20 \%)\end{array}$ \\
\hline $\begin{array}{l}\text { Guararino et al., } \\
\text { (2013) }\end{array}$ & $25 \mathrm{mg} / \mathrm{kg}$ & 24 months aged wistar rats & ITT and gene expression & $\begin{array}{l}\uparrow \text { insulin sensibility }(40 \%) \\
\text { NEFA (NC) } \\
\text { Epinephrine (NC) } \\
\uparrow \text { AMPK }(60 \%) \\
\uparrow \text { Glut4 }(50 \%)\end{array}$ \\
\hline $\begin{array}{l}\text { Moisey et al } \\
\quad(2008)\end{array}$ & $5 \mathrm{mg} / \mathrm{kg}$ & 8 healthy men & OGTT & $\begin{array}{l}\uparrow \text { insulin }(29 \%) \\
\uparrow \text { peptide C }(40 \%) \\
\uparrow \text { blood glucose }(147 \%)\end{array}$ \\
\hline Park et al (2007) & $35 \mathrm{mg}$ & $\begin{array}{l}\text { Sprague-Dawley diabetic } \\
\text { pancreatectomized rats }\end{array}$ & $\begin{array}{c}\text { Hyperglycemic clamp during } \\
\text { OGTT }\end{array}$ & $\begin{array}{l}\uparrow \text { insulin sensibility (25\%) } \\
\uparrow \text { glucokinase }(50 \%) \\
\uparrow \text { hyperplasia cell } \beta(21 \%) \\
\uparrow \text { IGF }(25 \%)\end{array}$ \\
\hline
\end{tabular}




\begin{tabular}{|c|c|c|c|c|}
\hline $\begin{array}{l}\text { Petrie et al } \\
\quad(2004)\end{array}$ & $5 \mathrm{mg} / \mathrm{kg}$ & 9 obese men & OGTT & $\begin{array}{l}\uparrow \text { Insulin }(36 \%) \\
\uparrow \text { peptide C }(35 \%) \\
\uparrow \text { FFA }(60 \%) \\
\downarrow \text { ISI }(25 \%)\end{array}$ \\
\hline $\begin{array}{l}\text { Robinson et al., } \\
\text { (2004) }\end{array}$ & $5 \mathrm{mg} / \mathrm{kg}$ & Obese men with DMT2 & OGTT & $\begin{array}{l}\uparrow \text { insulin }(25 \%) \\
\uparrow \text { peptide C }(26 \%) \\
\uparrow \text { glycemia }(25 \%) \\
\downarrow \text { ISI }(14 \%)\end{array}$ \\
\hline $\begin{array}{l}\text { Urzua } \text { et al. } \\
\text { (2012) }\end{array}$ & $93 \mathrm{mg} / \mathrm{kg}$ & $\begin{array}{l}\text { Streptozotocin-induced } \\
\text { diabetes mellitus rats }\end{array}$ & OGTT & $\downarrow$ glycemia $(19 \%)$ \\
\hline $\begin{array}{l}\text { Wedick et al., } \\
\text { (2011) }\end{array}$ & $\mathrm{N} / \mathrm{E}$ & $\begin{array}{c}45 \text { man over weight }(B M I= \\
\left.25-30 \mathrm{~kg} / \mathrm{m}^{2}\right)\end{array}$ & ISI, OGTT & $\begin{array}{l}\text { insulin sensibility (NC) } \\
\text { glucose tolerance (NC) } \\
\text { insulin secretion (NC) }\end{array}$ \\
\hline $\begin{array}{l}\text { Yamauchi et al., } \\
\qquad(2010)\end{array}$ & $290 \mathrm{mg} / \mathrm{L}$ & $\begin{array}{l}\text { Mice spontaneously diabetic } \\
\text { (KK-Ay }\end{array}$ & ITT and gene expression & $\begin{array}{l}\downarrow \text { glycemia }(30 \%) \\
\uparrow \text { insulin sensibility }(50 \%) \\
\downarrow \text { IL-6 }(40 \%) \\
\downarrow \text { TNF-a }(30 \%)\end{array}$ \\
\hline
\end{tabular}

N/E: Not evaluated; NA: No alterations; OGTT: Oral Glucose tolerance test; ITT: Insulin Tolerance Test; ISI: insulin sensibility index; ORAC: oxygen radical absorbance capacity; NF-kB: factor nuclear kappa B; FFA: free fatty acids; NEFA: non-esterified fatty acids; AMPK: 5'-AMP activated protein kinase; IGF: insulin growth factor; IL-6: interleukin-6; TNF- $\alpha$ : tumor necrosis factor.

\section{Insulin sensibility and glucose tolerance assessment after caffeine consumption}

Battram et al (2006) investigate the acute $(4,5 \mathrm{mg} / \mathrm{kg})$ and chronic (two weeks) effect of caffeine in healthy men $(23 \pm 0.6$ years, $74 \pm 1.9 \mathrm{~kg}$ ) over glucose and insulin homeostasis. The results of OGTT (Oral Glucose tolerance test) suggest an increase in insulin and peptide $\mathrm{C}$ concentrations after the consumption of caffeine, where compared to placebo group and decaffeinated one. However, the glucose levels after 90 minutes of test were 50\% higher compared to place and decaffeinated groups. After $12 \mathrm{~min}$. though, a glycemic control occurred, with no difference between groups. The glycerol concentration increases during caffeine consumption (126 to $154 \mathrm{umol} / \mathrm{L}$ ) after $60 \mathrm{~min}$, compared to other groups, as well as epinephrine concentration, which increased in the caffeine groups in 60,90 and $120 \mathrm{~min}$. compared to control groups. Robinson et al., (2004) evaluate obese men with DMT2. Caffeine was able to increase insulin (25\%) and serum glycemia (25\%) levels, after OGTT, demonstrating that caffeine alters blood glucose maintenance in diabetic men. Moisey et al (2008) demonstrated in their study with healthy men, that the consumption of caffeine $(5 \mathrm{mg} / \mathrm{kg})$ before OGTT increase blood glucose (147\%), insulin (29\%) and peptide C (40\%) compared to the values of decaffeinated control group after $60 \mathrm{~min}$.

Petrie et al (2004) assessed the effect of caffeine (5 $\mathrm{mg} / \mathrm{kg}$ ) over glucose and insulin homeostasis in obese men. After OGTT caffeine increased $36 \%$ the concentration of serum insulin without altering the values of blood glucose, however, with a decrease of insulin sensibility evaluated by insulin sensibility index (ISI) rates. In a study with diabetic rats Urzua et al (2012) gave $93 \mathrm{mg} / \mathrm{kg}$ of caffeine daily (the same of 3 cups of coffee) for 60 days. In nondiabetic animals, caffeine did not trigger any difference in blood glucose levels, however, in both groups the OGGT was favorable. Conde et al. (2012) evaluated the long-temp (15 days) caffeine consumption $(6.78 \mathrm{mg} / \mathrm{kg})$ in healthy rats and rats that received a fat diet. Caffeine revert insulin resistance condition of the animals which received the fat diet, restoring plasmatic insulin levels and controlling glucose and free fatty acid levels. This study also showed that the administration of caffeine was able to control the catecholamine levels (adrenaline and noradrenaline) in this group, reducing them up to $124 \%$ when comparing to the values of pre-consumption and further decreased sympathetic nervous system stimulation. Wedick et al. (2011) evaluated the effect of the consumption of 5 cups of coffee (caffeinated and decaffeinated) for 8 weeks, over DMT2 risk factors, in 45 men over weighed. No alteration was observed in the following parameters: ISI, oral glucose tolerance test (OGTT) and insulin secretion. In a study made by Guarino et al. (2013), it was demonstrated that chronic caffeine consumption $(25 \mathrm{mg} / \mathrm{kg})$ controlled glucose and fatty acids levels and reverted insulin resistance condition induced by aging in wistar rats. These effects were measured by the increase of AMPK activity and translocation of GLUT4. Bhaktha et al. (2015), demonstrated that long-term consumption of caffeine may be efficient in controlling glucose and adiponectin levels, which would be good for the prevention as well as for the associated complication of diabetes mellitus.

Some studies demonstrated metabolic mechanism after caffeine administration. Park et al. (2007) investigated the effect and mechanisms of caffeine $(30 \mathrm{mg})$ and sucrose $(21 \mathrm{~g})$ over glycemic metabolism of pancreatectomized Sprague-Dawley diabetic rats. After 12 weeks of caffeine administration, the animals exhibited an increase in insulin sensibility, without any alteration in glucose levels, and an increase of glucose-stimulated insulin, and also occurring hyperplasia of $\beta$ cells. An insulinotropic effect was observed, which may be explained by signalization cascade of insulin-1 growth factor (IGF-1) and increase in glucokinase activity. Besides that, sucrose consumption worsened insulin sensibility and attenuated the IGF-1 signalization in pancreatic islets. These findings indicate that long-term consumption of caffeine, further than altering the glycemic metabolism, also increased insulin sensibility and beta cells function in diabetic animals. Egawa et al. (2009) evaluate the effect of caffeine $(3 \mathrm{mmol} / \mathrm{L})$ over glucose capitation evolved in 
the metabolism regulation, in epitrochlearis cells and soleus muscles of rats, in vitro. Caffeine increased the phosphorylation of AMPK and acetyl coenzyme A carboxylase, associated with the reduction of phosphocreatine. An increase in glucose transportation rate was also demonstrated, by the activation of 3O-methyl-D glucose carrier, which is not stimulated by insulin. These results suggest that the effect of caffeine is similar to the physical exercise, improving and increasing glucose capitation through the activation of AMPK and glucose carriers that are not associated to insulin.

Yamauchi et al. (2010) evaluated the antidiabetic effect of coffee and caffeine consumption in spontaneously diabetic mice (KK-Ay). Coffee intake improved the hyperglycemic condition (2 fold), increased insulin sensibility and reduced inflammatory factors (IL-6 and TNF- $\alpha$ ). Caffeine consumption (290 mg/L) also improved the hyperglycemic condition and enhanced insulin sensibility. Chu et al. (2011) conducted a study to evaluate the action of bioactive compounds of coffee over antioxidant, inflammatory factors (inhibition of NF-Kb and TNF- $\alpha$ ) and the stimulation of glucose capitation in vitro. Bioactive compounds of coffee (phenolic compounds and caffeine) demonstrated a cellular antioxidant action in oxygen radical absorbance capacity (ORAC) test in hepatocytes with human HEPG2 carcinoma, as well as the capability of reducing $\mathrm{NF}-\mathrm{Kb}$ activation and increase glucose capitation in human adipose cells.

\section{Caffeine biological effect in the organism}

Regarding to fasting and postprandial glycemic values, caffeine consumption reverts and controls hyperglycemic levels typical of the diabetic condition, and also controls the plasmatic insulin levels. Caffeine administered before the oral glucose tolerance test (OGTT) in doses between 4.5 and $93 \mathrm{mg} / \mathrm{kg}$ did not alter glycemic and insulin values after $30 \mathrm{~min}$. However, after 60 and 90 minutes, caffeine tend to maintain glycemic and insulin levels high, comparing to groups without caffeine. This occurs to healthy, obese with glucose intolerance, diabetic men and also to diabetic rats or rats that received fat diets. Nonetheless, after 120 min, no difference was observed in glucose and plasmatic insulin concentrations.

Caffeine may alter insulin sensibility and glucose tolerance during OGTT, at short term. The studies demonstrated that caffeine consumption reduced the insulin sensibility by ISI rates, but modified glucose tolerance condition during OGTT. Insulin action reduction and glucose capture increase may be the key to explaining this enigma. Mechanisms that are insulinindependent (AMPK, 3-O-methyl-D-glucose carrier, glucokinase and GLUT2) may be sensitized during the action of caffeine triggering a better glucose tolerance and interaction of caffeine molecule over adenosine receptors.

The increase of CNS activity is associated with the increase of catecholamine circulation that trigger insulin resistance (Seals and Bell, 2004), which triggers an increase of lipolysis in adipose tissue, enhancing non-esterified fatty acids (NEFA) levels (Lafontan and Langin, 2009), increasing gluconeogenesis and glycogenesis stimulus, contributing to the hepatic glucose production (Exton and Park 1968; Exton et al., 1972). The endogenous increase of glucose associated with glucose capitation decrease in skeletal muscle and the oxidation of fatty acids (Young et al., 1985; Acheson et al., 2004; Mulder et al. 2005) cause hyperglycemia.

On long-term, studies demonstrated that caffeine did not alter (Wedick et al., 2011) or increased glucose tolerance (Guarino et al., 2013) and insulin sensibility (Yamauchi et al., 2010).

Other caffeine interaction reflects over glycerol plasmatic levels during OGTT, which is maintained elevated after the administration of the substance. The increase of fatty acids and glycerol with the action of caffeine over adenosine receptors enhances AMPc levels and fostering fatty acid mobilization. Battram et al. (2006) demonstrated an increase in catecholamine, fatty acid and plasmatic glucose levels during OGTT to the group of healthy men that received caffeine acutely, however, Conde et al (2012) demonstrated in rats with glucose tolerance that chronic consumption of caffeine (15 days) reduced the levels of catecholamines, fatty acids and plasmatic glucose.

In hyperglycemic conditions, the increase of insulin and triglycerides synthesis are stimulated, being opposed action ways. The main point about the influence of caffeine in glucose, insulin, fatty acids and glycerol levels during the metabolic state is curious, because this increase is contradictory to the liberation and synthesis of these substrates. This phenomenon may be explained by the upregulation of AMPK, effect of $\mathrm{Ca}^{2+}$ intracellular input triggered by caffeine (Jensen et al., 2007), which increased the action of the enzyme activated in GLUT4, CaMKII and ERK1/2, conduction a higher glucose and fatty acids capitation to the cells. Nonetheless, few studies aimed to elucidate the action of caffeine over the predominance of substrates and their entrance to cellular oxidation.

\section{Future directions}

Regarding to the evaluation of glycemic and fatty acids control, it is important to have consensus based on the best type of evaluation to verify the homeostasis of the energetic substrates metabolism, as well as on the evolvement of caffeine over the control, maintenance, consumption and synthesis of these substrates.

The condition of glucose tolerance becomes better with the consumption of caffeine in some studies, however, in others, this condition is worsened. There is a need of clarification regarding to the accuracy of the evolvement of this drug over the consumption and oxidation of energetic substrates related to cellular metabolism.

Insulin sensibility is perhaps a paradox when the effects of caffeine appear. This mechanisms and consequent alterations triggered by caffeine in the metabolism, in order to understand its pharmacology and its possible benefits and harms.

There is a need for studies that demonstrate the action of caffeine over: the glycemic and fatty acids behavior fo the alteration of catecholamine levels, insulin sensibility, glucose 
tolerance in humans. Studies aiming to evaluate the mechanism and effects of caffeine in the homeostasis of energetic metabolism may contribute to the combat against condition such as glucose intolerance, insulin resistance and diabetes mellitus.

\section{CONCLUSION}

The divergences of caffeine effects may give us a clue to find how it operates in the organism, due to the biological actions of this molecule over different tissues. This may an antagonist role such as glycogenic (hepatocytes) and glycolytic (skeletal muscle and adipose tissue) conditions, corresponding to adenosine receptors and $\mathrm{Ca}^{2+}$ intracellular concentrations, which influence the presence of enzymes that regulate metabolic substrates.

Furthermore, long-term consumption of caffeine seems to be more efficient in controlling glucose and adiponectin levels, which would be beneficial to the prevention as well as to the complication that are inherent to diabetes mellitus. Thus, with different action pathways, and with recent studies reporting favorable condition in the glycemic control in diabetes condition, caffeine may help controlling this disease that plague the world.

\section{Financial support and sponsorship: Nil.}

Conflict of Interests: There are no conflicts of interest.

\section{REFERENCES}

Acheson KJ., Gremaud G., Meirim I., Montigon F., Krebs Y., Fay L.B., Gay LJ., Schneiter P., Schindler C., Tappy, L. Metabolic effects of caffeine in humans: lipid oxidation or futile cycling? Am J Clin Nutr, 2004;79, 40-6

Battram DS., Arthur R., Weekes A., Graham TE. The glucose intolerance induced by caffeinated coffee ingestion is less pronounced than that due to alkaloid caffeine in men. J Nutr, 2006;136, 1276-80.

Bhaktha G., Nayak B.S., Mayya S., Shantaram M. Relationship of Caffeine with Adiponectin and Blood Sugar Levels in Subjects with and without Diabetes. Journal of Clinical and Diagnostic Research, 2015;9, 1-3

Canto C., Chibalin AV., Barnes BR., Glund S., Suarez E., Ryder JW., Palacin M., Zierath JR., Zorzano A., Guma A. Neuregulins mediate calcium-induced glucose transport during muscle contraction. J Biol Chem, 2006;281, 21690-7.

Chu YF., Chen Y., Black RM., Brown PH., Lyle BJ., Liu RH. Type 2 diabetes-related bioactivities of coffee: assessment of antioxidant activity, NF- $\kappa \mathrm{B}$ inhibition, and stimulation of glucose uptake. Food Chem, 2011;124, 914-20.

Conde SV., Silva TN., Gonzalez C., Carmo MM., Monteiro EC., Guarino MP. Chronic caffeine intake decreases circulating catecholamines and prevents diet-induced insulin resistance and hypertension in rats. Br J Nutr, 2012;107, 86-95.

Egawa T., Hamada T., Kameda N., Karaike K., Ma X., Masuda S., Iwanaka N., Hayashi T. Caffeine acutely activates $5^{\prime}$ adenosine monophosphate-activated protein kinase and increases insulin-independent glucose transport in rat skeletal muscles. Metabolism, 2009;58, 1609-17.

Exton JH., Friedmann N., Wong EH., Brineaux JP., Corbin JD., Park CR. Interaction of glucocorticoids with glucagon and epinephrine in the control of gluconeogenesis and glycogenolysis in liver and of lipolysis in adipose tissue. J Biol Chem, 1972;247, 3579-88.

Exton JH., Park CR. Control of gluconeogenesis in liver. II. Effects of glucagon, catecholamines, and adenosine $3^{\prime}, 5^{\prime}$-monophosphate on gluconeogenesis in the perfused rat liver. J Biol Chem, 1968;243, $4189-4196$
Fredholm BB., Bättig K., Holmén J., Nehlig, A., Zvartau EE. Actions of caffeine in the brain with special reference to factors that contribute to its widespread use. Pharmacol Rev, 1999;51, 83-133.

Guarino MP., Ribeiro MJ., Sacramento JF., Conde SV. Chronic caffeine intake reverses age-induced insulin resistance in the rat: effect on skeletal muscle Glut4 transporters and AMPK activity. Age (Dordr), 2013;35, 1755-65.

Jensen TE., Rose AJ., Hellsten Y., Wojtaszewski JF., Richter EA. Caffeine-induced $\mathrm{Ca}^{2+}$ release increases AMPK-dependent glucose uptake in rodent soleus muscle. Am J Physiol Endocrinol Metab, 2007;293, 286-292.

Kerr D., Everett J. Coffee, diabetes and insulin sensitivity. Diabetologia, 2005;48, 1418.

Lafontan M., Langin D. Lipolysis and lipid mobilization in human adipose tissue. Prog Lipid Res, 2009;48, 275-97

Long YC., Zierath JR. AMP-activated protein kinase signaling in metabolic regulation. J Clin Invest, 2006;116, 1776-83

Luo Z., Saha AK., Xiang X., Ruderman NB. AMPK, the metabolic syndrome and cancer. Trends Pharmacol Sci, 2005; 26, 6976.

Moisey LL., Kacker S., Bickerton AC., Robinson LE., Graham TE. Caffeinated coffee consumption impairs blood glucose homeostasis in response to high and low glycemic index meals in healthy men. Am J Clin Nutr, 2008;87, 1254-61

Mukwevho E., Kohn TA., Lang D., Nyatia E., Smith J., Ojuka EO. Caffeine induces hyperacetylation of histones at the MEF2 site on the Glut4 promoter and increases MEF2A binding to the site via a CaMKdependent mechanism. Am J Physiol Endocrinol Metab, 2008;294, 582588.

Mulder AH., Tack CJ., Olthaar AJ., Smits P., Sweep FC., Bosch RR. Adrenergic receptor stimulation attenuates insulin-stimulated glucose uptake in 3T3-L1 adipocytes by inhibiting Glut4 translocation. Am J Physiol Endocrinol Metab, 2005;289, 627-633.

Nathan DM. Long-term complications of diabetes mellitus. N Engl J Med, 1993;328, 1676-85.

Park S., Scheffler TL., Gunawan AM., Shi H., Zeng C., Hannon KM. Chronic elevated calcium blocks AMPK-induced GLUT-4 expression in skeletal muscle. Am J Physiol Cell Physiol, 2009;296, 10615.

Park S., Jang JS., Hong SM. Long-term consumption of caffeine improves glucose homeostasis by enhancing insulinotropic action through islet insulin/insulin-like growth factor 1 signaling in diabetic rats. Metabolism Clinical Experimental, 2007;56, 599-607.

Petrie HJ., Chown SE., Belfie LM., Duncan AM., McLaren DH., Conquer JA., Graham TE. Caffeine ingestion increases the insulin response to an oral-glucose-tolerance test in obese men before and after weight loss. Am J Clin Nutr, 2004;80, 22-8.

Raney M.A., Turcotte LP. Evidence for the involvement of CaMKII and AMPK in Ca2+-dependent signaling pathways regulating FA uptake and oxidation in contracting rodent muscle. J Appl Physiol, 2008;104, 1366-73.

Robinson LE., Savani S., Battram DS., McLaren DH., Sathasivam P., Graham TE. Caffeine Ingestion Before an Oral Glucose Tolerance Test Impairs Blood Glucose Management in Men with Type 2 Diabetes. J Nutr, 2004;134, 2528-33.

Rose AJ., Hargreaves M. Exercise increases $\mathrm{Ca}^{2+} /$ calmodulindependent protein kinase II activity in human skeletal muscle. J Physiol, 2003;553, 303-9.

Rose AJ., Richter EA. Skeletal muscle glucose uptake during exercise: how is it regulated? Physiology, 2005;20, 260-70.

Ruderman NB., Saha AK. Metabolic syndrome: adenosine monophosphate-activated protein kinase and malonyl coenzyme A. Obesity (Silver Spring), 2006;14, 25-33.

Sartorelli DS., Fagherazzi G., Balkau B. Differential effects of coffee on the risk of type 2 diabetes according to meal consumption in a French cohort of women: the E3N/EPIC cohort study. Am J Clin Nutr, 2010;91, 1002-12. 
Seals DR., Bell C. Chronic sympathetic activation: consequence and cause of age-associated obesity? Diabetes, 2004;53, 27684.

Urzúa Z., Trujillo X., Huerta M., Trujillo-Hernández B., RíosSilva M., Onetti C., Ortiz-Mesina M., Sánchez-Pastor E. Effects of chronic caffeine administration on blood glucose levels and on glucose tolerance in healthy and diabetic rats. J Int Med Res, 2012;40, 2220-30.

van Dam RM., Dekker JM., Nijpels G. Coffee consumption and incidence of impaired fasting glucose, impaired glucose tolerance, and type 2 diabetes: the Hoorn study. Diabetologia, 2004;47, 2152-2159

van Dam RM., Hu FB. Coffee consumption and risk of type 2 diabetes: a systematic review. JAMA, 2005;294, 97-104.

van Dam RM., Willett WC., Manson JE. Coffee, caffeine, and risk of type 2 diabetes: a prospective cohort study in younger and middleaged U.S. women. Diabetes Care, 2006;29, 398 - 403.

Wedick NM., Brennan AM., Sun Q., Hu FB., Mantzoros CS., van Dam RM. Effects of caffeinated and decaffeinated coffee on biological risk factors for type 2 diabetes: a randomized controlled trial. Nutr J, 2011;10, 93. doi: 10.1186/1475-2891-10-93.

World Health Organization. Screening for Type 2 Diabetes: Report of a World Health Organization and International Diabetes Federation Meeting. 2016. (available at: http://www.who.int/diabetes/publications/en/s creening_mnc03.pdf).

Wright DC., Geiger PC., Holloszy JO., Han DH. Contractionand hypoxia-stimulated glucose transport is mediated by a $\mathrm{Ca}^{2+}$-dependent mechanism in slow-twitch rat soleus muscle. Am J Physiol Endocrinol Metab, 2005;288,1062-66.

Wright DC., Hucker KA., Holloszy JO., Han DH. $\mathrm{Ca}^{2+}$ and AMPK both mediate stimulation of glucose transport by muscle contractions. Diabetes, 2004;53, 330-5.
Yamaji T., Mizoue T., Tabata S. Coffee consumption and glucose tolerance status in middle-aged Japanese men. Diabetologia, 2004; 47, 2145-51

Yamauchi R., Kobayashi M., Matsuda Y., Ojika M., Shigeoka S., Yamamoto Y., Tou Y., Inoue T., Katagiri T., Murai A., Horio F. Coffee and caffeine ameliorate hyperglycemia, fatty liver, and inflammatory adipocytokine expression in spontaneously diabetic KK-Ay mice. J Agric Food Chem, 2010;58, 5597-603.

Young DA., Wallberg-Henriksson H., Cranshaw J., Chen M., Holloszy JO. Effect of catecholamines on glucose uptake and glycogenolysis in rat skeletal muscle. Am J Physiol, 1985;248, 406-409.

\section{How to cite this article:}

daSilva LA, Wouk J, Weber VM, Eltchechem CL, Almeida P, Martins JCL, Malfatti CR, Osiecki R. Mechanisms and biological effects of Caffeine on substrate metabolism homeostasis: A systematic review. J App Pharm Sci, 2017; 7 (06): 215-221. 